\title{
HUBUNGAN ANTARA KOMPETENSI PEDAGOGIK DAN KOMPETENSI KEPRIBADIAN DENGAN PROFESIONALISME GURU DALAM MENJAWAB TANTANGAN PENDIDIKAN AGAMA ISLAM DI ERA INDUSTRI 4.0
}

\author{
Lia Rosita Dewi \\ Guru PAI SD di Kecamatan Bulakamba Kabupaten Brebes. \\ Dewilia934@gmail.com
}

DOI: 10.24235/oasis.v5i2.6149

$\begin{array}{lcc}\text { Received } & \text { Revised } & \text { Approved } \\ 2020-02-29 & 2020-03-06 & 2021-02-09\end{array}$

\begin{abstract}
Teachers have a significant role in the educational system. In the Industrial Age 4.0, teachers are expected to continue to develop theirselves to answer the challenges of today's education. This article describes the relationship between pedagogic competence and personality competence with the professionalism of Islamic education teachers in elementary schools in Bulakamba District, Brebes Regency. This study uses correlational quantitative methods (correlation design). The results of this study indicate that increasing pedagogic competence and personality competence will increase teacher professionalism and can improve the quality of education.
\end{abstract}

Keywords : Pedagogical competence, personal competence, teacher professionalism

\begin{abstract}
Abstrak
Guru menjadi ujung tombak utama keberhasilan dalam penyelenggaraan pendidikan. Di Era Industri 4.0, seorang guru diharapkan dapat terus mengembangkan dirinya untuk menjawab tantangan pendidikan saat ini. Artikel ini menjelaskan hubungan antara kompetensi pedagogik dan kompetensi kepribadian dengan profesionalisme guru PAI di SD di Kecamatan Bulakamba Kabupaten Brebes. Penelitian ini menggunakan metode kuantitatif korelasional (correlation design). Hasil penelitian ini menunjukkan bahwa semakin meningkat kompetensi pedagogik dan kompetensi kepribadian maka akan meningkat profesionalisme guru dan dapat meningkatkan mutu pendidikan.
\end{abstract}

Kata Kunci : Kompetensi pedagogik, kompetensi kepribadian, profesionalisme guru 


\section{PENDAHULUAN}

Guru menjadi ujung tombak utama keberhasilan dalam penyelenggaraan pendidikan. Pada praktiknya, guru yang ada di Indonesia masih terbelit dengan berbagai problematika yang dihadapinya, terkait dengan kompetensi guru, pemerataan jumlah guru, dan kesejahteraan guru. Berbagai upaya telah dilakukan oleh pemerintah untuk meningkatkan kemampuan yang dimiliki oleh pendidik melalui inisiasi Musyawarah Guru Mata Pelajaran (MGMP), Pendidikan Profesi Guru (PPG) hingga sertifikasi pendidik. Semua hal itu diselenggarakan dalam rangka meningkatkan kualitas pendidik di Indonesia.

Banyak pendidik yang mengalami berbagai kendala, baik yang berkenaan dengan teknis pembelajaran, maupun pada non-teknis di luar kegiatan belajarmengajar. Salah satu contohnya adalah adanya dalam perubahan kurikulum yang terjadi hamper pada tiap pergantian menteri. Pergantian kurikulum yang terjadi setiap pergantian kepemimpinan menyebabkan banyak kendala di lapangan yang harus dihadapi oleh guru dan kemudian berdampak pula pada peserta didik dan lembaga pendidikan itu sendiri.

Keberhasilan seorang guru dalam mengemban tugasnya, baik sebagai murabbi maupun sebagai agen perubahan dalam masyarakat sangat dipengaruhi oleh kualifikasi dan kompetensi yang mereka miliki. Seorang guru dituntut untuk mempunyai kualifikasi dan kompetensi yang memadai agar menjadi guru yang berhasil. Maka, untuk menjadi seorang guru dibutuhkan beberapa persyaratan dasar yang sebaiknya dimiliki oleh setiap guru (Abuddin, 2012).
Berkaitan dengan kompetensi guru, seperti disebutkan dalam UndangUndang Guru dan Dosen No. 14 Tahun 2005 pasal 10, di mana terdiri dari empat kompetensi diantaranya: kompetensi pedagogik, kompetensi kepribadian, kompetensi sosial, dan kompetensi profesional. Artinya kompetensi pedagogik dan profesional memiliki peran yang lebih dominan dan terukur dalam menentukan kualitas kompetensi mengajar guru dibandingkan dengan kompetensi kepribadian dan sosial. Maka tidak heran, jika dalam setiap pelaksanaan program pelatihan dan pengembangan guru yang digagas oleh pemerintah, dua kompetensi ini sama sekali tidak mendapat perhatian. Materi yang disampaikan berkaitan dengan masalah kurikulum dan penerapannya. Ironisnya, materi tentang peningkatan kompetensi guru sangat minim diberikan karena seringkali hanya berkutat pada halhal yang sifatnya administratif, seperti pendataan guru.

Menurut BP3K (Balai Penelitian Pengembangan Pendidikan dan Kebudayaan) tentang pengembangan kompetensi kepribadian, guru harus memiliki: (1) Pengetahuan tentang tata krama sosial dan agamawi; (2) Pengetahuan tentang kebudayaan dan tradisi; (3) Hakikat demokrasi dan makna demokrasi pancasila; (4) Apresiasi dan ekspresi estetika; (5) Kesadaran kewarganegaraan dan kesadaran sosial yangdalam; (6) Sikap yang tepat tentang ilmu pengetahuan kinerja; (7) Menjunjung tinggi martabat manusia. (Madyawati, 2012)

Pada dasarnya pilihan seseorang untuk menjadi seorang guru adalah, panggilan jiwa atau kemauan besar untuk 
memberikan pengabdian pada sesama manusia dengan mendidik, mengajar, membimbing, dan melatih yang diwujudkan melalui proses pembelajaran serta pemberiaan bimbingan dan pengarahan peserta didiknya agar mencapai kedewasaan masing-masing. (Sudarwan, 2013)

Seorang guru harus memahami hakikat pendidikan dan konsep yang terkait dengannya. Diantaranya yaitu fungsi dan peran lembaga pendidikan, konsep pendidikan seumur hidup dan berbagai implikasinya, peranan keluarga dan masyarakat dalam pendidikan, pengaruh timbal balik antara sekolah, keluarga, dan masyarakat, sistem pendidikan nasional, dan inovasi pendidikan (Jejen, 2012).

Dalam kenyataanya, menjadi seorang guru tidak cukup sekedar untuk memenuhi panggilan jiwa, tetapi juga memerlukan seperangkat keterampilan dan kemampuan khusus dalam bentuk menguasai kompetensi guru, sesuai dengan kualifikasi jenis dan jenjang pendidikan jalur sekolah tempatnya bekerja.

Ahmad Tafsir dalam Kosim (2019) menyebut, guru itu mesti memiliki sifat: kasih sayang kepada peserta didik, lemah lembut, rendah hati, menghormati ilmu yang bukan pegangannya, adil, menyenangi ijtihad, konsekuen antara perkataan dengan perbuatan, dan sederhana

Kompetensi merupakan perilaku rasional guna mencapai tujuan yang dipersyaratkan sesuai dengan kondisi yang diharapkan. Dengan demikian, suatu kompetensi ditujukan oleh penampilan atau kinerja yang dapat dipertanggung jawabkan (rasional) dalam upaya mencapai tujuan. Sebagai sebuah profesi, terdapat sejumlah kompetensi yang sebaiknya dimiliki oleh seorang guru, yaitu kompetensi pedagogik, kompetensi kepribadian, kompetensi sosial, dan kompetensi professional (Rahman Abd, 2012).

Upaya-upaya secara komprehensif perlu terus dilakukan agar kualifikasi dan kompetensi guru tercapai sesuai dengan harapan kita bersama dan memenuhi standar yang ditetapkan oleh pemerintah, termasuk pada jenjang sekolah dasar (SD), seperti di kecamatan bulakamba kabupaten brebes. Hal tersebut dilakukan agar kualifikasi dan kompetensinya sesuai dengan yang diharapkan. Generasi muda Indonesia diharapkan siap dan percaya diri menghadapi berbagai tantangan dan perubahan yang terjadi akibat pengaruh dari revolusi industri 4.0.

Imadudin dalam Kosim (2019) menyatakan bahwa Pendidikan di era revolusi industri 4.0, disebut juga dengan pendidikan $4.0 \quad$ (education 4.0) merupakan istilah umum digunakan oleh para ahli pendidikan untuk menggambarkan berbagai cara untuk mngintegrasikan teknologi cyber baik secara fisik maupun tidak ke dalam pembelajaran (Priatmoko, 2018 : 2). Pendidikan 4.0 adalah fenomena yang merespons kebutuhan revolusi industri 4.0 di mana manusia dan mesin berinteraksi sekaligus diselaraskan untuk memperoleh solusi, bahkan inovasi baru

UNESCO menyebutkan tiga keterampilan penting yang harus dikuasai di abad 21 ini, yaitu; learning skills (berpikir kritis, kreatiif, kolaborasi, dan komunikasi), literacy skills (informasi, media, dan teknologi), dan life skills (keluwesan, kepemimpinan, inisiatif, produktivitas, dan bersosialisasi) 
(Piratmoko dan Dzakiyyah, 2020). Kemampuan pedagogi dalam hal teknologi dan konten juga menjadi sebuah kemampuan yang harus dimiliki oleh seorang guru. Hal ini menegaskan bahwa guru di era 4.0 ini juga dituntut untuk mampu mengintegrasikan proses pembelajaran dengan teknologi, terutama teknologi digital.

Kompetensi pedagogik guru dalam kaitannya dengan profesionalisme guru adalah hal yang sangat penting guna menjawab tantangan pendidikan di era industri 4.0. Hal tersebut memiliki pengaruh terhadap pembentukkan karakter siswa. Hal ini juga tentu tak lepas dari tujuan pendidikan era indutri 4 untuk memperoleh lulusan pendidikan yang kompten di era saat ini, bukan hanya anak mampu memanfaatkan ICT tetapi juga mampu kompeten dalam kemapuan literasi, berpikir kritis, memecahkan masalah, komunikasi, kolaborasi, dan memiliki kualitas karakter yang baik (Syamsuar dan Refliant, 2018) .

Di tengaah semakin meningkatanya komptensi yang harus dimiliki oleh seorang guru, muncul pertanyaan tentang bagaimana kompetensi pedagogi guru yang ada saat ini, khususnya guru PAI di tingkat Sekolah Dasar (SD).. Perencanaan pembelajaran merupakan salah satu kompetensi pedagogi yang harus dimiliki guru, yang akan bermuara pada pelaksanaan pembelajaran. Perencanaan pembelajaran dipandang sebagai suatu alat yang dapat membantu guru untuk menjadi berdaya guna dalam melaksanakan tugas dan fungsinya. Perencanaan dapat menolong pencapaian suatu sasaran secara lebih ekonomis, tepat waktu dan memberi peluang untuk lebih mudah dikontrol dan dimonitor dalam pelaksanaannya (Harjanto, 2010).

Penelitian yang dilakukan oleh Kosim (2019) tentang peluang dan tantangan pendidikan Islam era industri 4.0 serta strategi mahasiswa Pendidikan Agama Islam (PAI). Menurutnya, era revolusi industri 4.0 bukan ditakuti, tetapi harus dihadapi dengan sikap optimis. Era industri 4.0 mengandung sejumlah peluang bagi guru untuk eksis berperan sebagai pendidik sejati dengan keteladanan. Lebih lanjut dikatakan bahwa guru dan calon guru PAI harus memandang era ini sebagai peluang emas untuk meningkatkan kualitas pendidikan Islam yang lebih komprehensif dan universal. Sehingga, mereka tidak saja berpikir dan berjuang bagaimana kelak dirinya siap menjadi guru yang melahirkan peserta didik yang taat beribadah, tetapi lebih dari itu, menjadi guru PAI yang mencerdaskan peserta didik, teman sejawat, warga sekolah dan masyarakat agar menerapkan ajaran Islam secara kaffah dengan misi rahmatan lil 'alamin.

Berdasarkan latar belakang masalah yang telah penulis uraikan, maka dapat dirumuskan beberapa pokok masalah sebagai berikut: (a) Apakah terdapat hubungan antara kompetensi pedagogik dengan profesionalisme guru PAI SD di Kecamatan Bulakamba Kabupaten Brebes?; (b) Apakah terdapat hubungan antara kompetensi kepribadian dengan profesionalisme guru SD PAI di Kecamatan Bulakamba Kabupaten Brebes?; (c) Apakah terdapat hubungan antara kompetensi pedagogik dan kompetensi kepribadian dengan 
profesionalisme guru PAI SD di Kecamatan Bulakamba Kabupaten Brebes?.

\section{Metode}

Metode penelitian yang digunakan dalam penelitian ini adalah deskriptif dan verifikatif. Penelitian bersifat deskriptif karena penelitian bertujuan untuk menggambarkan, menjelaskan dan mendeskripsikan mengenai suatu fenomena tertentu secara sistemik dimana di dalamnya dilakukan pengumpulan data dan menguraikannya secara menyeluruh dan teliti sesuai dengan permasalahan yang akan dipecahkan (Husein, 2013). Dalam penelitian ini yaitu tentang hubungan antara Kompetensi Pedagogik dan Kompetensi Kepribadian dengan Profesionalisme Guru PAI SD di Kecamatan Kabupaten Brebes tahun ajaran 2018-2019.

Pendekatan yang digunakan dalam penelitian ini adalah pendekatan kuantitatif, pendekatan ini digunakan karena peneliti akan mengukur hasil dari beberapa variabel yang telah ditetapkan melalui statistik. Metode penelitian kuantitatif berlandaskan pada filsafat positivisme, yakni digunakan untuk meneliti pada populasi atau sampel tertentu. Metode ini disebut juga metode penelitian naturalistik karena penelitiannya dilakukan pada kondisi yang alamiah (natural setting). (Sugiyono, 2015)

Selain itu, penelitian bersifat verifikatif karena bertujuan untuk menguji hubungan antara variabel berdasarkan hipotesis penelitian yang telah dibuat. Metode deskriptif verifikatif digunakan untuk mengetahui permasalahan yang terdapat dalam penelitian secara lebih akurat mengenai objek-objek tertentu, menjelaskan hubungan antar variabel dan akibat yang dihasilkan serta menguji hipotesis yang digunakan dalam penelitian (Sugiyono, 2013).

Dalam upaya mendapatkan data penelitian, maka penulis menggunakan metode pengumpulan data melalui Kuesioner/Angket, Observasi dan dokumentasi untuk mendapatkan data sekunder.

Untuk menguji validitas instrumen, peneliti menggunakan proses validasi logis, yaitu dengan cara berhati- hati sejak awal penyusunan instrumen, yakni memecah variable menjadi sub variabel/ indikator-indikator yang dijabarkan menjadi pertanyaan-pertanyaan (Dendy, 1258).

Disamping dengan validasi logis, peneliti melakukan uji validitas dengan cara membandingkan nilai koefisien korelasi product moment dengan nilai $\mathrm{r}$ tabel. Dan untuk menentukan nilai koefisien korelasi Product Moment menggunakan rumus:

$$
\Gamma X Y=\frac{N \sum X Y-\left(\sum X\right)\left(\sum Y\right)}{\sqrt{\left[N \sum X^{2}-\left(\sum X\right)^{2}\right]\left[N \sum Y^{2}-\left(\sum Y\right)^{2}\right]}}
$$

rxy= Koefisien Korelasi skor butir (X) dengan skor total (Y)

$\mathrm{X}=$ Skor item $/$ skor butir

$\mathrm{Y}=$ Skor total

$\mathrm{N}=$ Banyaknya subyek penelitian Sedangkan Uji Reliabilitas adalah instrumen yang bila digunakan beberapa kali untuk mengukur obyek yang sama, akan menghasilkan data yang samax(Sugiyono, 2013). Untuk mencari reliabilitas instrumen, penelitian ini menggunakan metode Alpha Cronbach. 
Hasil uji reliabilitas angket kompetensi pedagogik didapatkan dengan bantuan SPSS for window 22. Hasil reliabilitas menunjukkan bahwa angket kompetensi pedagogik mempunyai tingkat reliabilitas 0,951, jika diinterpretasikan maka reliabilitas angket kompetensi pedagogik termasuk kategori sangat tinggi.

Instrumen penelitian adalah alat yang digunakan untuk memperoleh, mengolah, dan menginterpretasikan informasi yang diperoleh dari responden yang dilakukan menggunakan pola ukur yang sama (Siregan, 2013).

Sedangkan dalam teknik analisis Data sesuai data yang dikumpulkan proses selanjutnya melalui analisis dengan menggunakan Uji asumsi klasik terdiri dari

1. Uji normalitas

Uji normalitas untuk menguji data variabel bebas $(\mathrm{X})$ dan variabel terikat (Y) pada persamaan regresi yang dihasilkan, apakah berdistribusi normal atau berdistribusi tidak normal. Jika distribusi data normal, maka analisis data dan pengujian hipotesis digunakan statistik parametrik. (Ghozali, 2005)

2. Uji Heteroskedastisitas

Multikolineritas bertujuan untuk apakah dalam model regresi ditemukan adanya korelasi antar variabel bebas (independen), model regresi yang baik seharusnya tidak terjadi kolerasi antar di antara variabel independent. Untuk mendeteksi multikolinearitas dapat melihat (1) nilai tolerance dan lawannya (2) Variance Inflating Factor (VIF). Kedua ukuran menunjukkan setiap independen manakah yang dijelaskan oleh variabel dependent lainnya. Batas
VIF adalah 10 dan nilai tolerance value 0,1 . Jika nilai VIF $>10$ dan nilai tolerance value $<0,1$ maka terjadi multikolinearitas, model regresi bebas dari multikolinearitas jika nilai VIF < 10 dan tolerance value $>, 0,10$ maka tidak terjadi multikolinearitas.(Ghozali, 2005)

3. Uji Multikolineritas

Autokorelasi merupakan korelasi antara anggota observasi yang disusun menurut satu tempat. Model regresi yang baik seharusnya tidak terjadi autokorelasi (Ghozali, 2005).

4. Uji Autokorelasi.

Autokorelasi merupakan korelasi antara anggota observasi yang disusun menurut satu tempat. Model regresi yang baik seharusnya tidak terjadi autokorelasi (Ghozali, 2005).

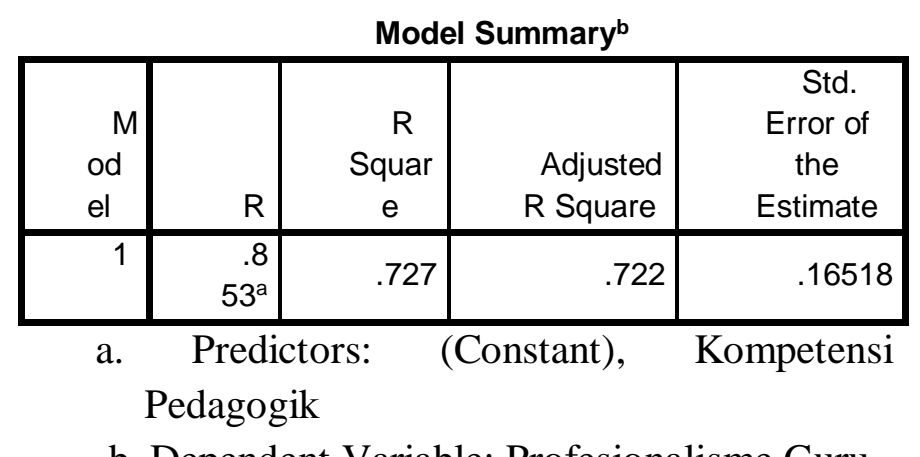

b. Dependent Variable: Profesionalisme Guru 
semakin tinggi kompetensi pedagogik maka akan meningkatkan profesionalisme guru.

Ho $=$ Tidak ada hubungan kompetensi pedagogik (X1) dengan profesionalisme guru $(\mathrm{Y}) . \mathrm{Ha}=$ Ada hubungan kompetensi pedagogik (X1) dengan profesionalisme guru (Y).

Langkah yang dilakukan sebelum melakukan hipotesis adalah menghitung persamaan regresi sederhana variabel kompetensi pedagogik X1) dengan profesionalisme guru (Y).

Tabel I

Tabel Anova dan koefisien regresi $\mathrm{X} 1$ dengan $\mathrm{Y}$.

Tabel III

Coefficients $^{\mathrm{a}}$

\begin{tabular}{|r|r|r|r|r|r|}
\hline & \multicolumn{2}{|c|}{$\begin{array}{c}\text { Unstandard } \\
\text { ized } \\
\text { Coefficients }\end{array}$} & $\begin{array}{c}\text { Standa } \\
\text { rdized } \\
\text { Coefficie } \\
\text { nts }\end{array}$ & & \\
\cline { 2 - 6 } Model & $\mathrm{B}$ & $\begin{array}{r}\text { Std. } \\
\text { Error }\end{array}$ & Beta & $\mathrm{t}$ & Sig. \\
\hline 1 (Constant) & $\begin{array}{r}1.1 \\
35\end{array}$ & .271 & & 4.190 & .000 \\
Kompetensi & .76 & .066 & .853 & 11.54 & .000 \\
Pedagogik & 6 & .066 & & \\
\hline
\end{tabular}

a. Dependent Variable: Profesionalisme Guru

Dari hasil uji analisis pada tabel di atas diperoleh nilai Fhitung $=133.27$ dengan tingkat probilitas 0,000. Oleh karena itu $0,000<0,05$ maka model regresi bisa dipakai untuk memprediksi profesionalisme guru.

Berdasarkan tabel kooefisien regresi pada tabel di atas dapat dilihat bahwa koefisien regresi sebesar 0,853 dan konstanta sebesar 1,135 serta harga $\mathrm{t}$ hitung dan tingkat signifikan sebesar 0,001 artinya apabila tidak ada variabel kompetensi pedagogik maka profesionalisme guru akan naik sebesar 1,135. Koefisien regresi sebesar 0,853 menyatakan setiap penambahan satu poin pada variabel kompetensi pedagogik maka diprediksikan akan meningkatkan profesionalisme guru sebesar 0,853. Jadi hal ini menyatakan arah prediksi yang searah atau linear. Kenaikan variabel X1 akan mengakibatkan kenaikan variabel bebas (Y). Dari kedua koefisien diperoleh persamaan regresi $\mathrm{Y}=1,135+0,853 \mathrm{X} 1$. Persamaan regresi ini dapat ditunjukkan dalam bentuk grafik sebagai berikut:

Tabel II

ANOVA $^{\mathrm{a}}$

\begin{tabular}{|l|r|r|r|r|r|}
\hline Model & $\begin{array}{r}\text { Sum of } \\
\text { Squares }\end{array}$ & \multicolumn{1}{c|}{$\mathrm{df}$} & $\begin{array}{r}\text { Mean } \\
\text { Square }\end{array}$ & $\mathrm{F}$ & Sig. \\
\hline $\begin{array}{l}\text { Regres } \\
\text { sion }\end{array}$ & 3.636 & 1 & 3.636 & $\begin{array}{r}133 . \\
270\end{array}$ & $\begin{array}{r}.000 \\
\mathrm{~b}\end{array}$ \\
Residual & 1.364 & 50 & .027 & & \\
Total & 5.000 & 51 & & & \\
\hline
\end{tabular}

a. Dependent Variable: Profesionalisme Guru b.Predictors: (Constant), Kompetensi Pedagogik

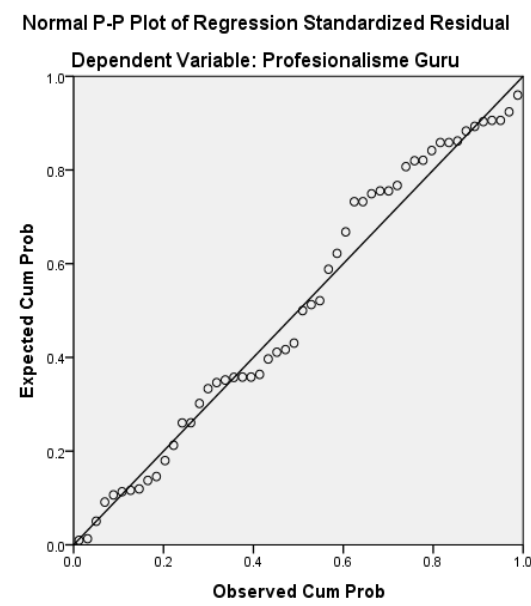

Grafik Hubungan antara Kompetensi Pedagogik dengan Profesionalisme Guru.

Dari gambar di atas dapat dilihat bahwa data menyebar di sekitar garis 
diagonal dan mengikuti arah garis diagonal maka data terdistribusi dengan normal dengan model regresi ini telah memenuhi normalitas.

Persamaan regresi $\mathrm{Y}=1,135+$ 0,853 X1 dapat diinterpretasikan bahwa apabila kompetensi pedagogik (X1) dan profesionalisme guru diukur dengan menggunakan instrumen ini, maka setiap kenaikan skor kompetensi pedagogik satu poin akan diikuti kenaikan skor profesionalisme guru 0,853 pada arah yang sama dengan konstanta 1.135.

Selanjutnya pengujian hipotesis dilanjutkan dengan menggunakan rumus korelasi Pearson Product Moment yang dihitung dengan bantuan SPSS 22. Berikut ini tabel hasil perhitungannya.

Untuk memberikan penjelasan lebih lanjut mengenai hubungan kompetensi pedagogik terhadap profesionalisme guru digunakan analisis korelasi parsial yakni analisis hubungan antara dua variabel dengan mengendalikan variabel lain yang dianggap mempengaruhi (dibuat konstan). Hal ini dimaksudkan agar hubungan kedua variabel tidak dipengaruhi oleh faktor lain. Hasil analisis ini akan menunjukkan koefisien korelasi untuk mengukur erat atau tidaknya hubungan, arah hubungan dan berarti atau tidaknya hubungan.

Tabel 4

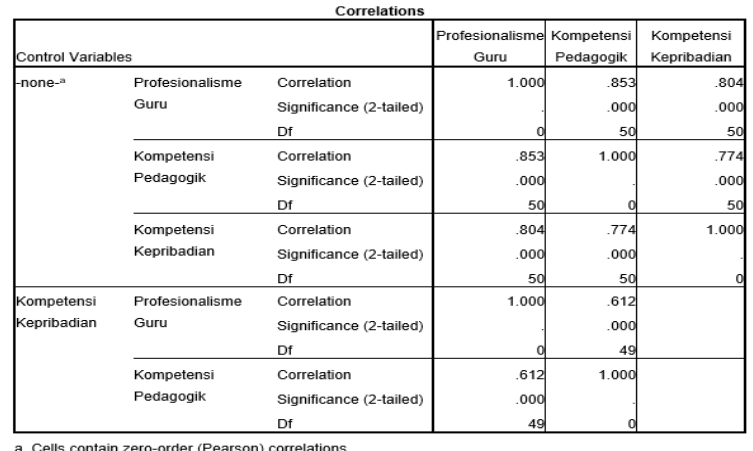

Dari tabel tampak jelas bahwa hubungan kompetensi pedagogic dengan profesionalisme guru sebelum kompetensi kepribadian dikendalikan memiliki korelasi positif dengan koefisien sebesar 0,853 dengan taraf signifikansi $0,000<0,05$ sehingga Ho ditolak dan $\mathrm{Ha}$ diterima artinya kedua variabel signifikan. Namun ketika variabel $\mathrm{X}_{2}$ dikendalikan ternyata hubungan kedua variabel yakni $\mathrm{X}_{1}$ dengan $\mathrm{Y}$ atau hubungan antara kompetensi pedagogic dengan profesionalisme guru mengalami penurunan nilai koefisien secara dratis yakni tinggal 0,612 dan taraf signifikansinya $0,000>0,05$ sehingga Ho ditolak dan Ha diterima artinya kedua variabel signifikan. Dapat pula dikatakan ada pengaruh yang berarti dari variabel kompetensi pedagogik terhadap profesionalisme guru jika kompetensi pedagogik dikontrol.

\section{Hubungan antara kompetensi kepribadian profesionalisme guru}

Hipotesis kedua dalam penelitian ini adalah terdapat hubungan kompetensi kepribadian $\left(\mathrm{X}_{2}\right)$ dan profesionalisme guru (Y). Diartikan bahwa semakin tinggi kompetensi kepribadian maka akan meningkatkan profesionalisme guru.

Ho = Tidak ada hubungan kompetensi kepribadian ( $\left.\mathrm{X}_{2}\right)$ dengan profesionalisme guru (Y). Ha = Ada hubungan kompetensi kepribadian $\left(\mathrm{X}_{2}\right)$ dengan profesionalisme guru (Y).

Langkah yang dilakukan sebelum melakukan hipotesis adalah menghitung persamaan regresi sederhana variabel 
kompetensi kepribadian $\mathrm{X}_{2}$ ) dengan profesionalisme guru (Y).

Tabel 5

Tabel Anova dan koefisien regresi $\mathrm{X}_{2}$ dengan $\mathrm{Y}$

\begin{tabular}{|c|c|c|c|c|c|c|}
\hline \multicolumn{7}{|c|}{ ANOVA $^{8}$} \\
\hline Mod & & Sum of Squares & df & Mean Square & $\mathrm{F}$ & Sig. \\
\hline \multirow[t]{3}{*}{1} & Regression & 3.234 & 1 & 3.234 & 91.581 & $.000^{b}$ \\
\hline & Residual & 1.766 & 50 & .035 & & \\
\hline & Total & 5.000 & 51 & & & \\
\hline
\end{tabular}

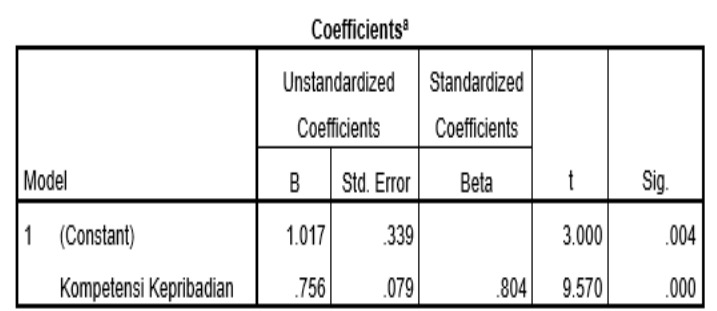

a. Dependent Variable: Profesionalisme Guru

Dari hasil uji analisis pada tabel di atas diperoleh nilai Fhitung $=91,581$ dengan tingkat probilitas 0,000 . Oleh karena itu $0,000<0,05$ maka model regresi bisa dipakai untuk memprediksi profesionalisme guru.

Berdasarkan tabel kooefisien regresi pada tabel di atas dapat dilihat bahwa koefisien regresi sebesar 0,804 dan konstanta sebesar 1,017 serta harga $\mathrm{t}$ hitung dan tingkat signifikan sebesar 0,000 artinya apabila tidak ada variabel kompetensi kepribadian $\left(\mathrm{X}_{2}\right)$ maka profesionalisme guru akan sebesar 1,017. Koefisien regresi sebesar 0,804 menyatakan setiap penambahan satu poin pada variabel kompetensi kepribadian $\left(\mathrm{X}_{2}\right)$ maka diprediksikan akan meningkatkan profesionalisme guru sebesar 0,804. Jadi hal ini menyatakan arah prediksi yang searah atau linear. Kenaikan variabel $\mathrm{X}_{2}$ akan mengakibatkan kenaikan variabel bebas (Y). Dari kedua koefisien diperoleh persamaan regresi $\mathrm{Y}=1,017+0,804 \mathrm{X}_{2}$. Persamaan regresi ini dapat ditunjukkan dalam bentuk grafik sebagai berikut:

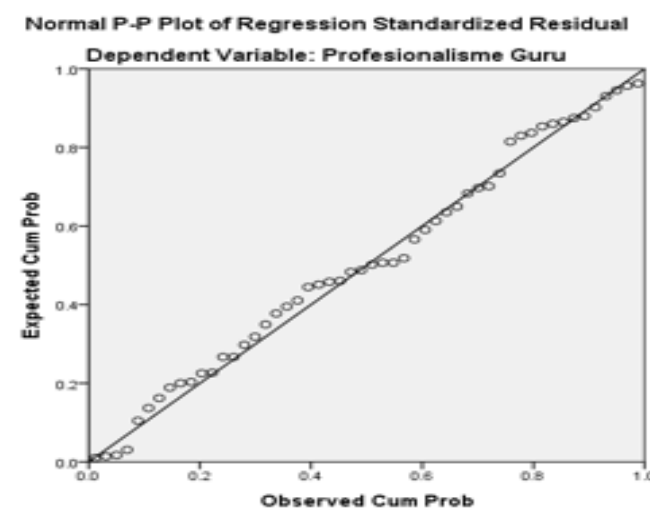

Grafik Hubungan antara Kompetensi kepribadian dengan Profesionalisme Guru

Dari gambar di atas dapat dilihat bahwa data menyebar di sekitar garis diagonal dan mengikuti arah garis diagonal maka data terdistribusi dengan normal dengan model regresi ini telah memenuhi normalitas.

Persamaan regresi $\mathrm{Y}=1,017+$ 0,804 $\mathrm{X}_{2}$ dapat diinterpretasikan bahwa apabila kompetensi kepribadian $\left(\mathrm{X}_{2}\right)$ dan profesionalisme guru diukur dengan menggunakan instrumen ini, maka setiap kenaikann skor kompetensi kepribadian $\left(\mathrm{X}_{2}\right)$ satu poin akan diikuti kenaikan skor profesionalisme guru 0,804 pada arah yang sama dengan konstanta 1,017.

Selanjutnya pengujian hipotesis dilanjutkan dengan menggunakan rumus korelasi Pearson Product Moment yang dihitung dengan bantuan SPSS 22. Berikut ini tabel hasil perhitungannya: 
Tabel 6

Korelasi $\mathrm{X}_{2}$ dengan $\mathrm{Y}$

Correlations

\begin{tabular}{|ll|r|r|}
\hline & & $\begin{array}{c}\text { Correlations } \\
\text { Guru }\end{array}$ & $\begin{array}{r}\text { Kompetensi } \\
\text { Kepribadian }\end{array}$ \\
\hline Profesionalisme Guru & Pearson Correlation & 1 & $.804^{\prime \prime}$ \\
& Sig. (2-tailed) & .000 \\
& $\mathrm{~N}$ & 52 & 52 \\
\hline Kompetensi Kepribadian & Pearson Correlation & $.804 "$ & 1 \\
& Sig. (2-tailed) & .000 & \\
& $\mathrm{~N}$ & 52 & 52 \\
\hline
\end{tabular}

**. Correlation is significant at the 0.01 level (2-tailed).

Berdasarkan hasil dari tabel di atas, diperoleh koefisien korelasi antara kompetensi kepribadian (X2) dengan profesionalisme guru dengan rxy $=0,804$ yang berarti terdapat hubungan yang positif di antara keduanya. Hal ini dapat pula dibuktikan dengan melihat uji signifikansinya. Kaidah untuk uji signifikansi adalah jika nilai probabilitas lebih besar atau sama dengan 0,05 dengan nilai probabilitas sig. Jika nilai probababilitas lebih kecil atau sama dengan nilai probabilitas 0,05, maka $\mathrm{Ha}$ diterima dan Ho ditolak artinya signifikan. Nilai 0,000 lebih kecil bila dibandingkan dengan 0,05 berarti hubungan kedua variabel signifikan.

Untuk memberikan penjelasan lebih lanjut mengenai hubungan kompetensi kepribadian $\left(\mathrm{X}_{2}\right)$ terhadap profesionalisme guru digunakan analisis korelasi parsial yakni analisis hubungan antara dua variable dengan mengendalikan variabel lain yang dianggap mempengaruhi (dibuat konstan). Hal ini dimaksudkan agar hubungan kedua variabel tidak dipengaruhi oleh faktor lain. Hasil analisis ini akan menunjukkan koefisien korelasi untuk mengukur erat atau tidaknya hubungan, arah hubungan dan berarti atau tidaknya hubungan.

Dari tabel tampak jelas bahwa hubungan kompetensi kepribadian $\left(\mathrm{X}_{2}\right)$ dengan profesionalisme guru sebelum kompetensi pedagogic dikendalikan memiliki korelasi positif dengan koefisien sebesar 0,804 dengan taraf signifikansi $0,000<0,05$ sehingga Ho ditolak dan $\mathrm{Ha}$ diterima artinya kedua variabel signifikan. Namun ketika variabel $\mathrm{X}_{2}$ dikendalikan ternyata hubungan kedua variabel yakni $\mathrm{X}_{2}$ dengan $Y$ atau hubungan antara kompetensi kepribadian $\left(\mathrm{X}_{2}\right)$ dengan profesionalisme guru mengalami penurunan nilai koefisien secara dratis yakni tinggal 0,437 dan taraf signifikansinya 0,001 >0,05 sehingga Ho ditolak dan Ha diterima artinya kedua variabel signifikan. Dapat pula dikatakan ada pengaruh yang berarti dari variabel kompetensi kepribadian $\left(\mathrm{X}_{2}\right)$ terhadap profesionalisme guru jika kompetensi kepribadian $\left(\mathrm{X}_{2}\right)$ dikontrol.

\section{Hubungan antara kompetensi pedagogik dan kompetensi kepribadian secara bersama- sama dengan profesionalisme guru}

Ho = Tidak ada hubungan kompetensi pedagogik $\left(\mathrm{X}_{1}\right)$ dan kompetensi kepribadian ( $\left.\mathrm{X}_{2}\right)$ dengan profesionalisme guru (Y).

$\mathrm{Ha}=$ Ada hubungan kompetensi pedagogik $\left(\mathrm{X}_{1}\right)$ dan kompetensi kepribadian $\left(\mathrm{X}_{2}\right)$ dengan profesionalisme guru (Y).

Langkah yang dilakukan sebelum melakukan hipotesis adalah menghitung persamaan regresi sederhana variabel kompetensi pedagogic $\mathrm{X}_{1}$ ) dan kompetensi 
kepribadian $\left(\mathrm{X}_{2}\right)$ dengan profesionalisme guru (Y).

\section{Tabel 7}

Tabel Anova dan koefisien regresi X1, X2 dengan Y

\begin{tabular}{|l|r|r|r|c|}
\hline Model & \multicolumn{1}{|c|}{ R } & Rodel Summary & \\
\hline 1 & $.883^{\circ}$ & .779 & \multicolumn{1}{c|}{$\begin{array}{c}\text { Adjusted R } \\
\text { Square }\end{array}$} & $\begin{array}{c}\text { Std. Error of the } \\
\text { Estimate }\end{array}$ \\
\hline
\end{tabular}

a. Predictors: (Constant), Kompetensi Kepribadian, Kompetensi Pedagogik b. Dependent Variable: Profesionalisme Guru

\begin{tabular}{|c|c|c|c|c|c|c|}
\hline & \multicolumn{6}{|c|}{ ANOVA' } \\
\hline Mod & & Sum of Squares & $d f$ & Mean Square & $\mathrm{F}$ & Sig. \\
\hline 1 & Regression & 3.896 & 2 & 1.948 & 86.464 & $.000^{\circ}$ \\
\hline & Residual & 1.104 & 49 & .023 & & \\
\hline & Total & 5.000 & 51 & & & \\
\hline
\end{tabular}

a. Dependent Variable: Profesionalisme Guru

b. Predictors: (Constant), Kompetensi Kepribadian, Kompetensi Pedagogik

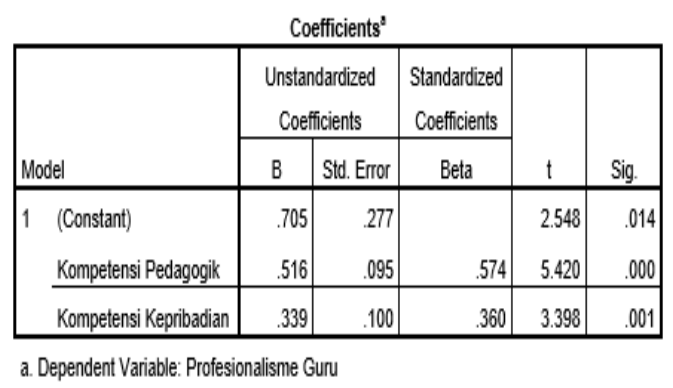

Nilai Ftabel untuk db1 $=2$ dan db2 $=\mathrm{n}-\mathrm{k}-1=52-2-1=49$ pada taraf signifikansi 0,05 adalah 3,18. Dari hasil uji analisis pada tabel di atas diperoleh nilai Fhitung $=86,464>3,18$ (ftabel), oleh sebab itu Ho ditolak dan Ha diterima. Hal ini berarti terdapat hubungan yang positif antara kompetensi pedagogik dan kompetensi kepribadian dengan profesionalisme guru. Juga berdasarkan nilai signifikansi dengan tingkat probilitas $0,000<0,05$. Jadi, dapat disimpulkan bahwa kompetensi pedagogik dan kompetensi kepribadian secara bersama-sama berpengaruh terhadap profesionalisme guru.

\section{Tabel 8}

Koefisien Korelasi $\mathrm{X}_{1}, \mathrm{X}_{2}$ dengan $\mathrm{Y}$

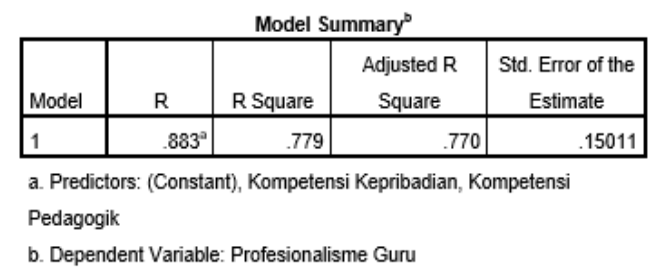

Dari tabel dapat dijelaskan bahwa nilai $\mathrm{R}$ sebesar 0,883 artinya korelasi antara dua variabel bebas yakni kompetensi pedagogik dan kompetensi kepribadian dengan variabel terikat profesionalisme guru sebesar 0,883 . Nilai $\mathrm{R}$ berkisar antara 0 sampai 1, jika mendekati angka 1 maka hubungan kedua variabel semakin erat tetapi jika mendekati 0 maka hubungan keduanya semakin lemah. Karena angka $\mathrm{R}$ didapat sebesar 0,883 maka ini berarti hubungan kedua variabel kuat.

Dan dapat disimpulkan Hasil dari penelitian yaitu :

\section{a. Hubungan antara kompetensi pedagogik dengan profesionalisme guru}

Hasil penelitian menunjukkan bahwa hubungan variabel kompetensi pedagogik terhadap profesionalisme guru memberikan kontribusi atau sumbangan sebesar $72,7 \%$ terhadap profesionalisme guru pada Guru PAI SD se Kecamatan Bulakamba Kabupaten Brebes. Hal ini mengindikasikan bahwa sumbangan variable kompetensi pedagogik dengan profesionalisme guru tergolong besar dalam peningkatan profesionalisme guru dimana factor lain hanya sebesar $27,3 \%$. 
Koefisien korelasi antara kompetensi pedagogic dengan profesionalisme guru dengan ryl $=0,853$ yang berarti terdapat hubungan positif yang kuat antara variabel kompetensi pedagogic dengan variable profesionalisme guru.

Kompetensi pedagogik mengandung makna komitmen terhadap tugas, ilmu pengetahuan, dan pengabdian sedangkan profesionalisme guru Profesionalisme guru adalah bahwa guru harus mempunyai pengetahuan yang luas serta subject matter (bidang studi) yang akan diajarkan serta penguasaan metodologis dalam arti memiliki metode yang tepat serta mampu menggunakannya dalam proses belajar mengajar.(Arikunto, 1993)

Dengan demikian dapat dikatakan bahwa terdapat hubungan yang positif antara kompetensi pedagogik dengan profesionalisme guru. Hasil yang demikian, menunjukkan bahwa kompetensi pedagogik memberikan kontribusi terhadap profesionalisme guru, sehingga guru mempunyai kemampuan untuk mengelola pembelajaran dengan metode, media dan sumber belajar yang tepat. Dengan berbekal kompetensi pedagogik yang baik maka akan baik pula tingkat profesionalisme guru.

\section{b. Hubungan antara Kompetensi kepribadian dengan profesionalisme guru}

Hasil penelitian menunjukkan bahwa hubungan variable kompetensi kepribadian terhadap profesionalisme guru memberikan kontribusi atau sumbangan sebesar $80,4 \%$ terhadap profesionalisme guru pada Guru PAI SD se Kecamatan Bulakamba Kabupaten Brebes. Hal ini mengindikasikan bahwa sumbangan variabel kompetensi kepribadian dengan profesionalisme guru termasuk besar dalam peningkatan profesionalisme guru dimana factor lain hanya sebesar 19,6\%. Koefisien korelasi antara kompetensi kepribadian dengan profesionalisme guru dengan ry1=0,804 yang berarti terdapat hubungan positif yang kuat antara variabel kompetensi kepribadian dengan variable profesionalisme guru.

Hasil yang demikian, menunjukkan bahwa kompetensi kepribadian memberikan kontribusi terhadap profesionalisme guru, sehingga guru harus mempunyai kompetensi kepribadian yang baik. untuk meningkatkan profesionalisme guru, seorang guru harus bekerja dengan dilandasi sikap amanah, tanggungjawab, disiplin dikarenakan seorang guru adalah teladan bagi peserta didik. Meskipun kompetensi kepribadian hanyalah salah satu faktor profesionalisme guru, personality guru sangat penting. Dengan demikian ada hubungan yang signifikan antara kompetensi kepribadian dengan profesionalisme guru.

\section{c. Hubungan antara kompetensi pedagogik dan kompetensi kepribadian secara bersama- sama dengan profesionalisme guru}

Hasil penelitian menunjukkan bahwa hubungan positif kompetensi pedagogik dan kompetensi kepribadian secara bersama-sama mempengaruhi profesionalisme guru. Hasil analisis regresi ganda diperoleh regresi ganda $\mathrm{R}$ sebesar 0,883 dengan signifikansi koefisien regresi ganda $\mathrm{F}$ sebesar 86.464 dengan persamaan regresi linear $\mathrm{Y}=0,705+0,516 \mathrm{X}_{1}+0,339$ $\mathrm{X}_{2}$. Nilai $\mathrm{R}=$ sebesar 0,883 artinya korelasi 
antara dua variabel bebas yakni kompetensi pedagogik dan kompetensi kepribadian dengan variable terikat profesionalisme guru sebesar $88,3 \%$. Nilai $\mathrm{R}$ berkisar antara 0 sampai 1, jika mendekati angka 1 maka hubungan kedua variabel semakin erat tetapi jika mendekati 0 maka hubungan keduanya semakin lemah. Karena angka $\mathrm{R}$ didapat sebesar 0,883 maka ini berarti hubungan kedua variabel kuat.

Hasil ini menunjukkan pentingnya variabel kompetensi pedagogic dan kompetensi kepribadian secara bersamasama untuk meningkatkan profesionalisme guru, karena kedua variabel ini secara bersama-sama dapat menjelaskan variansi profesionalisme guru sebesar 77,9. Dari persamaan regresi ganda dapat diartikan, bahwa semakin tinggi kompetensi pedagogik dan kompetensi kepribadian akan meningkatkan profesionalisme guru.

Dari uraian di atas, dijelaskan bahwa kompetensi pedagogik adalah kemampuan guru mengelola pembelajaran, kompetensi kepribadian adalah kemampuan guru dalam bertutur kata dan bertingkah laku yang mulia dalam melaksanakan tugasnya, dan profesionalisme guru adalah kemampuan guru dalam melaksanakan tugas dengan professional dan bertanggungjawab sehingga mampu menghantarkan peserta didik hidup mandiri. Untuk menjadi seorang guru yang profesional maka seorang guru harus mempunyai kompetensi pedagogik dan kompetensi kepribadian yang baik. Dengan demikian kompetensi pedagogik, kempetensi kepribadian memiliki hubungan signifikan dengan profesionalisme guru.

\section{Kesimpulan}

Dari beberapa pembahasan yang telah dilakukan penulis sebelumnya dapat disimpulkan beberapa poin penting, di antaranya adalah:

1. Koefisien korelasi antara kompetensi pedagogik dengan profesionalisme guru dengan ry1= 0,853 yang berarti terdapat hubungan yang signifikan antara kompetensi pedagogik dengan profesionalisme guru di Kecamatan Bulakamba Kabupaten Brebes. Berdasarkan hasil analisis data diketahui bahwa variabel kompetensi pedagogik berpengaruh terhadap profesionalisme guru. Hal ini ditunjukkan dari hasil uji t yang probabilitas $<0,05$.

2. Koefisien korelasi antara kompetensi kepribadian dengan profesionalisme guru dengan ryl= 0,804 yang berarti terdapat hubungan yang signifikan antara kompetensi kepribadian dengan profesionalisme guru di Kecamatan Bulakamba Kabupaten Brebes. Berdasarkan hasil analisis data diketahui bahwa variabel kompetensi kepribadian berpengaruh terhadap profesionalisme guru. Hal ini ditunjukkan dari hasil uji $\mathrm{t}$ yang probabilitas $<0,05$.

3. Hasil analisis regresi ganda diperoleh regresi ganda $\mathrm{R}_{12}$ sebesar 0,883 dengan signifikansi koefisien regresi ganda $\mathrm{F}$ sebesar 86.464 dengan persamaan regresi linear $\mathrm{Y}$ 
$=0,705+0,516 \mathrm{X}_{1}+0,339 \mathrm{X}_{2}$.

Koefisien korelasi antara kompetensi pedagogik dengan profesionalisme guru dengan ryl= 0,883 yang berarti terdapat hubungan yang signifikan antara kompetensi pedagogik dan kompetensi kepribadian secara bersama-sama dengan profesionalisme guru di Kecamatan Bulakamba Kabupaten Brebes yang ditunjukkan dari hasil uji $\mathrm{t}$ yang probabilitas $<0,05$.

\section{Daftar Pustaka}

Abuddin, N. (2012). Sejarah Pendidikan Islam (Cet III). jakarta: Rajawali Pers.

Arikunto. (1993). Prosedur Penelitian Suatu Pendekata Praktik. Jakarta: Rineka Cipta.

Dendy. (1258). Kamus Besar Bahasa Indonesia. Jakarta: Gramedia.

Ghozali, I. (2005). Aplikasi Analisis Multivirate dengan Program SPSS. Semarang. Retrieved from Badan Penerbit Universitas diponegoro

Harjanto. (2010). Perencanaan Pengajaran. Jakarta: PT Rineka Cipta.

Husein, U. (2013). Metode Penelitian untuk Skripsi dan Tesis. jakarta: PT Raja Agung Persada.

Jejen, M. (2012). Peningkatan Kompetensi Guru. jakarta: Kencana Prenada media Group.

Kosim, Muhammad, (2019). Peluang dan Tantangan Pendidikan Islam Era Industri 4.0: Strategi Mahasiswa PAI menjadi Pendidik Sejati., Jurnal Murabby: Jurnal Pendidikan Islam, Vol. 2 Nomor 2, September 2019

Madyawati. (2012). Kompetensi Profesional dan Kompetensi Kepribadian. Jakarta: Bumi Aksara.

Priatmoko, s. Dzakiyyah, Nina, I. (2020) Relevansi Kampus Merdeka terhadap Kompetensi Guru Era 4.0 Perspektif Experiential Learning Theory. AtThullab: Jurnal Pendidikan Guru Madrasah Ibtidaiyah. Vol.4 No.1.

Rahman Abd, G. (2012). Мепији Guru Profesional dan ber-etika (Cet VIII). Yogyakarta: Graha Guru. 
Siregan, S. (2013). Metode Penelitian Kuantitatif Dilengkapi dengan Perhitungan Manual dan SPSS. jakarta: Kencana Prenadamedia Group.

Sudarwan, D. (2013). Profesionalisasi dan Etika Profesi Guru (Cet III). Bandung: Alfabeta.

Sugiyono. (2013). Metode Penelitian Pendidikan Pendekatan Kuantitaif, Kualitatif, dan R\&D. Metode Penelitian Pendidikan Pendekatan Kuantitaif, Kualitatif, Dan $R \& D$. https://doi.org/10.1016/j.tiv.2011.06.0 08

Sugiyono. (2015). Metode Penelitian Pendidikan: Pendekatan Kuantitatif, Kualitatif dan $R \& D$, Edisi $I V$. bandung: alfabeta.

Syamsuar dan Reflianto. (2018). Pendidikan Dan Tantangan Pembelajaran Berbasis Teknologi Informasi Di Era Revolusi Industri 4.0. E-tech: Jurnal Ilmiah Tekonolgi Pendidikan. Vol.6, No.2

Tobi'in. (2020). Wawancara dengan Pengawas PAI kecamatan Bulakamba. 